\title{
PENGARUH KONSENTRASI PEKTIN DALAM SUHU DAN WAKTU PENYIMPANAN BERBEDA TERHADAP KARAKTERISTIK PELEMBAB KULIT
}

\author{
Herlina Eva Fitriani, Supriyono Eko W*, Amry Syawaalz \\ Program Studi Kimia FMIPA Universitas Nusa Bangsa Bogor \\ Jl. KH Soleh Iskandar KM 4 Cimanggu Tanah Sareal Bogor 1616 \\ *e-mail : Supriyono.wardoyo@yahoo.com
}

\section{ABSTRACT \\ Effect of Concentration of Pectin in Different Temperature and Storage Time on Characteristics of Skin Moisturizing}

\begin{abstract}
The use of pectin as a substituent a synthetic material in the manufacture of skin moisturizers can support the reuse of natural ingredients for skin care. This study aimed to obtain optimum concentrations in the preparation of skin moisturizers and to see the characteristics of skin moisturizer with the addition of the pectin concentration. The result showed the optimum concentration of pectin in the preparation of moisturizing the skin with a concentration of $0.05 \%$ with a characteristic appearance (viscosity) was most preferably, the $\mathrm{pH}$ value of 7.08 ; a specific gravity of $0.98 \mathrm{~g} / \mathrm{ml}$; viscosity of $2229 \mathrm{cP}$, emulsion stability of $100 \%$, and there was no microbial contamination in accordance with the standard of quality of skin moisturizers
\end{abstract}

Keyword:. Pectin, concentration, characteristics, skin moisturizing

\begin{abstract}
ABSTRAK
Penggunaan pektin sebagai pensubstitusi bahan sintetik dalam pembuatan pelembab kulit dapat mendukung penggunaan kembali bahan-bahan alami untuk perawatan kulit. Penelitian ini bertujuan untuk mendapatkan konsentrasi optimum dalam sediaan pelembab kulit dan mempelajari karakteristik pelembab kulit dengan penambahan konsentrasi pektin. Hasil penelitian didapatkan konsentrasi optimum pektin dalam sediaan pelembab kulit dengan konsentrasi 0,05\% dengan karakteristik penampakan (kekentalan) yang paling disukai, nilai pH 7,08; bobot jenis $0,98 \mathrm{~g} / \mathrm{ml}$; viskositas $2229 \mathrm{cP}$, stabilitas emulsi $100 \%$, dan tidak terdapat cemaran mikroba sesuai dengan syarat mutu pelembab kulit..
\end{abstract}

Kata kunci: Pektin, konsentrasi, karakteristik, pelembab kulit

\section{PENDAHULUAN}

Pada saat ini kebutuhan kosmetika hampir menjadi kebutuhan yang dianggap penting bagi sebagian orang. Hal ini dikarenakan penggunaan kosmetika tidak hanya terbatas untuk mempercantik dan merawat diri saja tetapi juga untuk tujuan kesehatan. Namun, diikuti banyak produkproduk kosmetika beredar yang membahayakan bagi kesehatan pemakainya, akibat dari kandungan bahan didalamnya yang menimbulkan efek negatif.

Pelembab kulit merupakan salah satu jenis kosmetika yang digunakan untuk melembabkan kulit. Kosmetika ini terdiri dari air, pelembab, pelembut, pengental, pengawet, dan pewangi (Mitsui, 1997).
Dalam formulasi pelembab kulit digunakan bahan pengental atau thickener agent. Salah satu bahan pengental sintetik adalah karbomer dan masuk ke dalam golongan alkrilamid. Kopolimer akrilamid berfungsi sebagai bahan flokulasi dan pengental (Otles, 2004). Akrilamid dapat membentuk rantai polimer panjang yang dikenal sebagai poliakrilamid, yang juga karsinogenik (Richard, 1984). Polimer ini dipakai dalam pengental karena ia akan membentuk gel bila tercampur air. Menurut Schmitt (1996), bahan-bahan yang termasuk ke dalam akrilamid dapat memicu partumbuhan penyakit kanker. Pada penelitian ini, bahan-bahan akrilamid diganti dengan bahan yang berasal dari alam, yaitu pektin. 
Penggunaan pektin sebagai pensubstitusi bahan sintetik dalam pembuatan pelembab kulit dapat mendukung penggunaan kembali bahan-bahan alami untuk perawatan kulit sehingga diharapkan dapat meningkatkan nilai jual produk pelembab kulit karena lebih aman untuk digunakan konsumen dan memperluas penggunaan bahan alam pektin di dalam industri kosmetika.

\section{BAHAN DAN METODE}

\section{Bahan}

Bahan yang digunakan dalam penelitian ini antara lain : pektin, asam stearat (Emery Oleochemicals (M) Sdn., Bhd.), gliseril monostearat PEG-100 stearat (Croda Singapore Pte., Ltd.), setil alkohol (Cention International, Inc.), minyak mineral (PT Worldwide Resin \& Chemicals), isopropil palmitat (KemOleo Pte., Ltd.), gliserin (PT Ecogreen Oleochemicals), triethanolamin (Ineos Oxide Ltd.), pewangi (PT Mane Indonesia), metil paraben (Clariant Production Pontypridd) dan air (PT Paragon Technology and Innovation).

\section{Peralatan}

Peralatan yang digunakan adalah timbangan digital (Shimadzu BL-320H), viskometer Brookfield tipe RV model DV II, piknometer, oven, $\mathrm{pH}$ meter (Pen Type), dan alat gelas.

\section{Prosedur kerja}

Pada tahap ini, bahan-bahan yang digunakan ditimbang menggunakan timbangan digital, dengan komposisi sebagai berikut: gliserin ditimbang sebanyak 10 gram, TEA ditimbang sebanyak 0,6 gram, dan air ditimbang sebanyak 169 gram dengan menggunakan piala gelas $250 \mathrm{ml}$ (fase air atau sediaan 1), asam stearat ditimbang sebanyak 3 gram, gliseril monostearat PEG-100 stearat ditimbang sebanyak 6 gram, setil alkohol ditimbang sebanyak 1 gram, minyak mineral ditimbang sebanyak 5 gram, isopropil palmitat ditimbang sebanyak 5 gram, dengan menggunakan cawan porselin $100 \mathrm{ml}$ (fase minyak atau sediaan 2). Kedua sediaan dipanaskan hingga suhu $70-75{ }^{\circ} \mathrm{C}$ sambil diaduk berkala, kemudian fase minyak (sediaan 2) dimasukkan ke dalam fase air (sediaan 1), aduk hingga homogen. Sediaan yang telah homogen tersebut dicampur dan diaduk dengan pengaduk mencapai suhu 40 ${ }^{\circ} \mathrm{C}$ (sediaan 3 ).

Pengawet (metil paraben) dan parfum ditimbang lalu dimasukkan ke dalam sediaan 3 pada suhu $35{ }^{\circ} \mathrm{C}$ kemudian, dilakukan pengadukan kembali selama kurang lebih satu menit. Sampel pektin ditimbang sesuai konsentrasi, lalu dihomogenkan dengan sedikit sediaan hingga homogen, kemudian dicampurkan ke dalam sediaan secara keseluruhan.

\section{1) Analisis penampakan}

Analisis penampakan berdasarkan pengamatan dilakukan terhadap viskositas pelembab kulit setelah proses pembuatan. Parameter ini dilakukan secara subyektifitas. Analisis penampakan menggunakan uji hedonik yang bertujuan untuk mengevaluasi daya terima atau tingkat kesukaan panelis terhadap produk yang dihasilkan. Skala hedonik yang digunakan antara 1-5 dimana : (1) tidak suka; (2) agak tidak suka; (3) normal; (4) agak suka; (5) suka. Pengujian dilakukan oleh 20 panelis wanita dengan kisaran usia 2026 tahun.

\section{2) Analisis pH}

Keasaman ( $\mathrm{pH})$ sediaan diukur menggunakan $\mathrm{pH}$-meter. Pengukuran $\mathrm{pH}$ sampel dilakukan dengan menggunakan pH-meter Pen Type yang sebelumnya telah dikalibrasi menggunakan larutan buffer $\mathrm{pH} 4$ dan $\mathrm{pH} 7$. Pengukuran dilakukan dengan membuat larutan sampel $5 \%$ kemudian mencelupkan sensor $\mathrm{pH}$ ke dalam sampel uji, lalu ditunggu sampai angka yang muncul pada layar stabil.

\section{3) Analisis Viskositas}

Sampel sebanyak 100 gram dimasukkan ke dalam wadah kemudian diukur viskositasnya dengan menggunakan viskometer Brookfield type RV DV-II 
(spindel no 3) dengan kecepatan 30 rpm. Pengujian viskositas disini menggunakan jenis viskositas absolut/ dinamik. Penentuan viscosity dilakukan dengan menggunakan alat viskometer Brookfield tipe RV dengan mengamati angka pada skala viskometer dengan kecepatan tertentu. Penentuan sifat alir dilakukan dengan menentukan viskositas pada berbagai kecepatan geser (rpm). Pemeriksaan ini dilakukan setelah satu hari pembuatan agar sesuai dengan kondisi ruang.

\section{4) Analisis Bobot Jenis}

Bobot jenis diukur menggunakan piknometer pada suhu $20{ }^{\circ} \mathrm{C}$. Pengukuran bobot jenis dengan piknometer yang dilengkapi termometer sebagai berikut, ditimbang seksama piknometer kosong (A), piknometer berisi air (B), dan piknometer berisi sediaan (C). Bobot jenis sediaan dihitung dengan rumus sebagai berikut :

$$
\text { BJ }=\frac{\mathrm{C}-\mathrm{A}}{\mathrm{B}-\mathrm{A}}
$$

5) Analisis Total Mikroba

Pengukuran total mikroba berdasarkan (Peraturan Ka.BPOM No. HK. 03.1.23.07.11.6662 Tahun 2011 Tentang Persyaratan Cemaran Mikroba dalam Kosmetik) adalah sebagai berikut, secara aseptis ditimbang sampel sebanyak 1 gram dan dimasukkan ke dalam larutan pengencer (garam fisiologis) kemudian dihomogenkan. Pengenceran dilakukan $10^{-1}$. Sebanyak $1 \mathrm{ml}$ dari sampel, diinokulasikan pada cawan petri steril. Media Tryptic Soy Agar (TSA) untuk ALT Bakteri, media Saboraud Dextrose Agar (SDA) untuk Angka Kapang Khamir, media Manitol Salt Agar (MSA) untuk Staphylococcus aureus, media Centrimide Agar (CA) untuk Pseudomonas aeruginosa. Media yang steril pada suhu $45-55{ }^{\circ} \mathrm{C}$ dituangkan pada cawan petri sebanyak $10-15 \mathrm{ml}$. Cawan petri digoyang dan dibiarkan memadat. Inkubasi dilakukan pada suhu $37{ }^{\circ} \mathrm{C}$ selama $18-24$ jam.

6) Analisis Stabilitas Emulsi

Pengukuran Sampel bahan emulsi dimasukkan dalam wadah dan ditimbang beratnya. Wadah dan bahan tersebut dimasukkan dalam oven dengan suhu $45{ }^{\circ} \mathrm{C}$ selama 1 jam kemudian dimasukkan ke dalam pendingin bersuhu dibawah $0{ }^{\circ} \mathrm{C}$ selama 1 jam dan dikembalikan lagi ke oven pada suhu $45{ }^{\circ} \mathrm{C}$ selama 1 jam. Pengamatan dilakukan terhadap kemungkinan terjadinya pemisahan air dari emulsi. Bila terjadi pemisahan, emulsi dikatakan tidak stabil dan tingkat kestabilannya dihitung berdasarkan persentase fase terpisahkan terhadap emulsi keseluruhan (Mitsui, 1997). Stabilitas emulsi dapat dihitung berdasarkan rumus berikut :

SE $(\%)=$

$100 \%$ - Berat fase memisah x $100 \%$ Berat total bahan emulsi

\section{HASIL DAN PEMBAHASAN}

\section{A. Pengujian Mutu Pelembab Kulit}

Pengujian dilakukan untuk menentukan kualitas pelembab kulit yang dihasilkan, dibandingkan dengan standar SNI 16-43991996.

\section{Penampakan}

Penampakan merupakan penilaian produk secara keseluruhan yang dapat terlihat dari luar. Penampakan yang diuji adalah viskositas pelembab kulit karena fungsi dari pektin sebagai pengental, dan untuk melihat respon panelis terhadap produk pelembab kulit setelah penambahan pengental pektin. Uji kesukaan terhadap parameter viskositas juga untuk mengetahui kesukaan panelis terhadap viskositas produk pada saat pemakaian karena terdapat beberapa pemakai yang menyukai pelembab kulit yang tidak terlalu kental. Penilaian dilakukan secara visual dengan cara 
meminta panelis melihat viskositas produk kemudian mengoleskannya pada kulit. Nilai kesukaan panelis yang diberikan terhadap viskositas pelembab kulit ditunjukkan oleh Gambar 1.

Nilai kesukaan panelis tertinggi terhadap viskositas produk dengan konsentrasi pektin $0,05 \%$ sedangkan terendah terhadap viskositas dengan konsentrasi pektin $0 \%$. Hal ini disebabkan pelembab kulit dengan konsentrasi pektin $0 \%$ memiliki viskositas yang rendah dibandingkan pelembab kulit lainnya dan panelis tidak terlalu menyukai pelembab kulit yang encer. Berdasarkan nilai kesukaan panelis tertinggi terhadap viskositas maka konsentrasi pektin 0,05\% merupakan pelembab kulit terbaik karena melihat fungsi pektin sebagai pengental.

\section{Nilai $\mathrm{pH}$}

Nilai pH merupakan nilai yang menunjukan derajat keasaman suatu bahan. Nilai rat-rata $\mathrm{pH}$ yang didapat berkisar antara 7,01-7,10. Nilai $\mathrm{pH}$ produk berada kisaran nilai $\mathrm{pH}$ SNI sehingga produk yang dihasilkan tidak akan menimbulkan efek pada kulit. Hal ini karena produk kosmetika yang memiliki nilai $\mathrm{pH}$ sangat tinggi atau sangat rendah akan menyebabkan kulit teriritasi (Wasitatmadja, 1997). Nilai pH produk pelembab kulit (yang diacu berdasarkan SNI 16-4399-1996 tentang sediaan tabir surya) disyaratkan berkisar antara 4,5-8,0. Levin dan Maibach (2007)* menyatakan bahwa $\mathrm{pH}$ yang terlalu asam atau basa dapat menyebabkan kulit menjadi kering dan mengalami iritasi karena terjadinya kerusakan mantel asam pada lapisan stratum corneum (salah satu bagian epidermis kulit). Nilai $\mathrm{pH}$ tertinggi pada pelembab kulit dengan konsentrasi pektin 0 $\%$ yaitu 7,10 sedangkan terendah pada pelembab kulit dengan konsentrasi pektin $0,20 \%$ yaitu 7,01 . Semua konsentrasi pektin yang digunakan masih memenuhi standar SNI. Berdasarkan hasil perhitungan statistik untuk parameter $\mathrm{pH}$ didapatkan hasil bahwa penambahan konsentrasi pektin adalah berpengaruh sangat nyata $(\mathrm{P}<0,01)$.

Semakin tinggi konsentrasi pektin yang digunakan maka nilai $\mathrm{pH}$ akan semakin menurun. Hal ini karena pektin yang digunakan bersifat asam (nilai $\mathrm{pH}$ berkisar 3,5) (Spesifikasi pektin produksi PT. Makmur Pangan Kharisma)

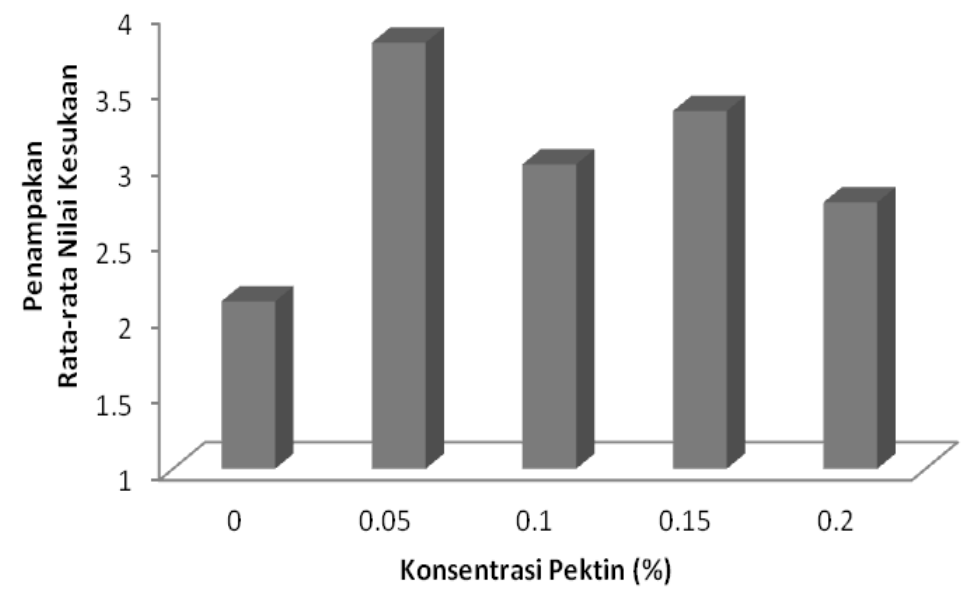

Gambar 1. Histogram Rata-rata Nilai Kesukaan Panelis terhadap Penampakan 


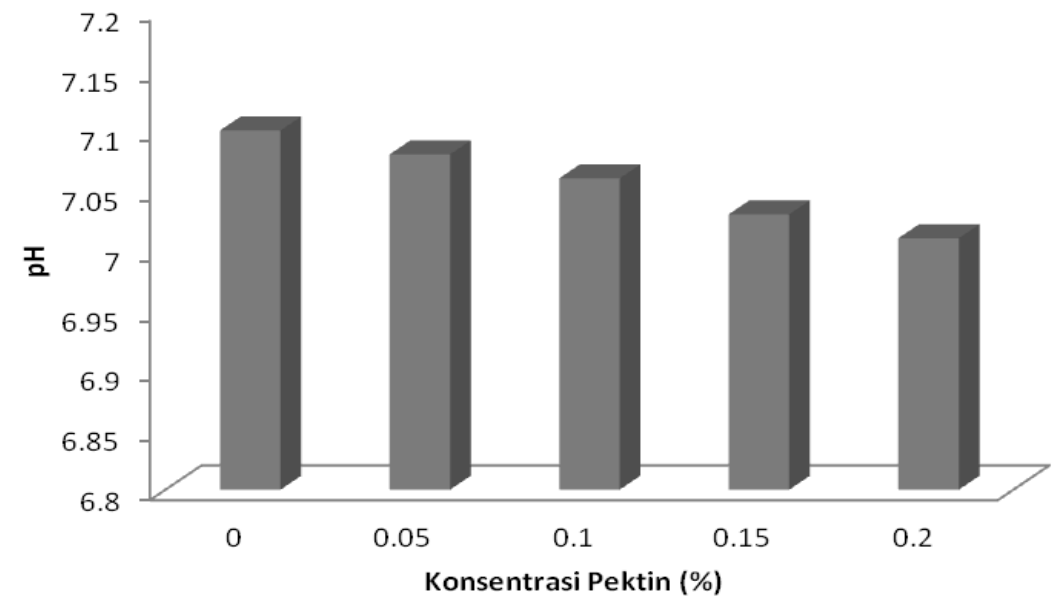

Gambar 2. Histogram Hubungan antara Konsentrasi Pektin dengan $\mathrm{pH}$

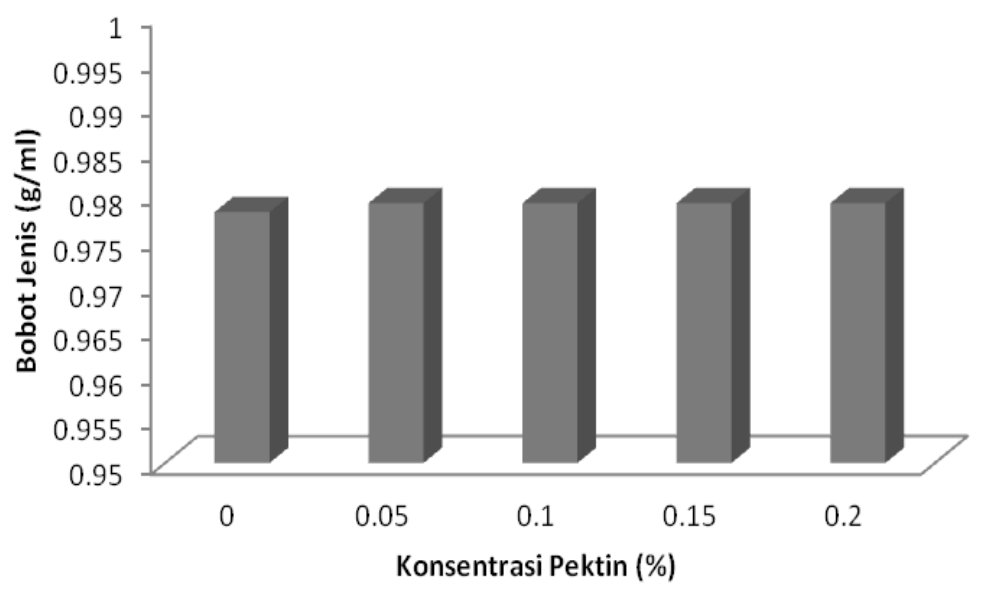

Gambar 3. Histogram Hubungan antara Konsentrasi Pektin dengan Bobot Jenis

\section{Nilai Bobot Jenis}

Bobot jenis adalah perbandingan bobot zat terhadap air dengan volume yang sama ditimbang di udara pada suhu yang sama. Gambar 3 menunjukkan berbagai konsentrasi pektin tidak begitu mempengaruhi kualitas pelembab kulit karena hampir semua nilai bobot jenis (BJ) pelembab kulit yang di hasilkan sama dan masih sesuai dengan standar SNI 16-4399-1996 yaitu 0,95-1,05 g/ml, karena konsentrasi pektin yang relatif kecil pada pelembab kulit, sehingga penambahan berbagai konsentrasi tersebut tidak memberikan pengaruh yang berarti terhadap bobot jenis pelembab kulit.

\section{Viskositas}

Viskositas merupakan salah satu parameter penting dalam produk-produk emulsi khususnya pelembab kulit. Faktor yang erat hubungannya dengan stabilitas emulsi adalah viskositas (Suryani et al.
2000). Nilai viskositas berkisar antara 19232874 cP (centipoise). Nilai viskositas terbesar diperoleh dari pelembab kulit dengan pektin $0,20 \%$ yaitu sebesar $2874 \mathrm{cP}$ sedangkan terkecil diperoleh dari pelembab kulit dengan pektin $0 \%$ yaitu $1923 \mathrm{cP}$. Semakin tinggi konsentrasi pektin yang digunakan semakin tinggi nilai viskositas emulsi pelembab kulit yang dihasilkan. Hal ini karena peranan pektin di dalam formulasi yang berfungsi sebagai pengental.

Nilai viskositas yang dihasilkan memenuhi kisaran standar nilai 2000-50000 cP (SNI 16-4399-1996), kecuali nilai viskositas pelembab kulit tanpa pektin (0 $\%)$. Hal ini karena tidak adanya bahan yang berfungsi sebagai pengental pada formulasi pelembab kulit dengan pektin $0 \%$ sehingga viskositas yang dihasilkan paling rendah. Nilai viskositas pelembab kulit yang dihasilkan dapat dilihat pada Gambar 4. 


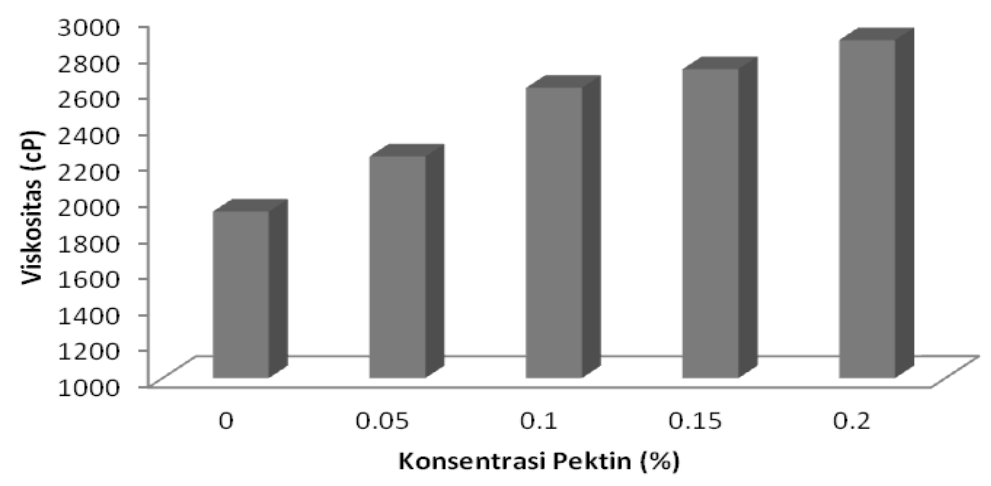

Gambar 4. Histogram Hubungan antara Konsentrasi Pektin dengan Viskostitas

Viskositas pektin meningkat dengan meningkatnya konsentrasi pektin yang digunakan. Hal ini karena semakin banyak gugus hidrofilik yang terkandung sehingga semakin banyak air dalam pelembab kulit yang dapat terikat oleh gugus tersebut dan mengakibatkan peningkatan viskositas pelembab kulit. Viskositas pektin terjadi pada saat dispersi pektin dalam bulk. Penggunaan koloid hidrofilik efektif untuk meningkatkan viskositas suatu emulsi minyak dalam air karena dapat meningkatkan viskositas fase pendispersi (fase air) tanpa menaikkan volume fase minyak dalam emulsi tersebut (Rieger 1994). Pada pelembab kulit dengan konsentrasi pektin $0,4 \%$ meningkat pula viskositasnya. Akan tetapi, mulai muncul tanda-tanda ketidakstabilan pada pelembab kulit tersebut.

\section{Total Mikroba}

Uji total mikroba adalah uji untuk mengetahui ada atau tidak adanya mikroba dalam pelembab kulit yang dihasilkan. Uji ini merupakan salah satu uji yang penting karena kontaminasi mikroba dapat menyebabkan pemisahan fase, iritasi dan bau yang tidak sedap. Pelembab kulit merupakan suatu produk yang memiliki jangka waktu pemakaian yang cukup lama, sehingga adanya mikroba dalam pelembab kulit dapat menjadi masalah terhadap daya awet pelembab kulit. Kontaminasi mikroorganisme walaupun bukan termasuk mikroorganisme pathogenik tidak diinginkan dalam kosmetika karena dapat menyebabkan terjadinya deteriorasi pada kualitas produk seiring waktu pemakaian dan akan menyebabkan iritasi kulit (Mitsui 1997). Uji total mikroba pada pelembab kulit menunjukkan bahwa tidak terdapat mikroba pada pelembab kulit yang dihasilkan. Penggunaan bahan pengawet pada formulasi (metil paraben) terbukti efektif untuk mencegah tumbuhnya mikroba yang dapat merusak produk pelembab kulit.

\section{B. Pengujian Mutu Pelembab Kulit Setelah 40 Hari Penyimpanan Suhu $27^{\circ} \mathrm{C}$}

\section{Penampakan}

Penampakan pelembab kulit penyimpanan suhu ruang $\left(27^{\circ} \mathrm{C}\right)$ setelah 40 hari, mengalami perubahan relatif kecil jika dibandingkan dengan pelembab kulit sebelum penyimpanan pada penyimpanan suhu ruang, jadi produk relatif stabil terlihat dari luar secara keseluruhan.

\section{Nilai $\mathrm{pH}$}

Derajat keasamaan $(\mathrm{pH})$ merupakan nilai yang menunjukkan sifat asam atau basa suatu bahan. Sifat keasaman suatu produk kosmetik sangat penting untuk diketahui karena pemakaiannya yang langsung berhubungan dengan kulit. Nilai rata-rata $\mathrm{pH}$ untuk produk pelembab kulit yang mengalami penyimpanan suhu ruang $\left(27^{\circ} \mathrm{C}\right)$ setelah 40 hari, tidak mengalami perubahan. Nilai rata-rata $\mathrm{pH}$ yang didapat masih berkisar antara 7,01-7,10. 
Nilai $\mathrm{pH}$ produk pelembab kulit yang baik yaitu masih masuk rentang SNI yaitu antara 4,5-8,0. Semua produk dengan konsentrasi pektin berbeda berada dalam kisaran $\mathrm{pH}$ tersebut. Artinya produk yang dihasilkan aman untuk kulit.

\section{Nilai Bobot Jenis}

Bobot jenis pelembab kulit setelah 40 hari penyimpanan pada suhu ruang $\left(27^{\circ} \mathrm{C}\right)$, masih sesuai dengan standar SNI 16-43991996 yaitu 0,95-1,05, karena konsentrasi pektin yang relatif kecil pada pelembab kulit, sehingga penambahan berbagai konsentrasi tersebut tidak memberikan pengaruh yang berarti terhadap Bj pelembab kulit.

\section{Viskositas}

Viskositas emulsi pelembab kulit dengan pektin $0,20 \%$ paling tinggi setiap waktu pengamatan selama penyimpanan suhu $27^{\circ} \mathrm{C}$. Viskositas merupakan salah satu faktor yang mempengaruhi stabilitas emulsi. Semakin tinggi viskositas suatu bahan, maka bahan tersebut akan semakin stabil karena pergerakan partikel cenderung sulit dengan semakin kentalnya suatu bahan (Schmitt, 1996).

Hasil pengukuran nilai viskositas selama penyimpanan berkisar antara 19232919 cP. Nilai dengan penambahan pektin tersebut masih termasuk ke dalam kisaran viskositas yang disyaratkan SNI 16-4399-
1996 yaitu berada dalam kisaran nilai viskositas 2000-50000 cP. Nilai viskositas ditunjukkan pada Gambar 5.

Berdasarkan analisis ragam dapat diketahui bahwa konsentrasi pektin, interval waktu penyimpanan dan interaksi antara konsentrasi pektin dengan lama penyimpanan mempengaruhi viskositas. Viskositas pelembab kulit selama penyimpanan suhu ruang $\left(27{ }^{\circ} \mathrm{C}\right)$ mengalami peningkatan viskositas pada penambahan konsentrasi pektin $0 \%$ dan $0,05 \%$ sedangkan pada penambahan pektin $0,10-0,20 \%$ relatif stabil selama penyimpanan. Biasanya viskositas emulsi meningkat dengan meningkatnya umur emulsi tersebut (Rieger 1994). Emulsi yang tidak stabil cenderung mengalami penurunan viskositas selama penyimpanan (Suryani et al. 2000).

\section{Total Mikroba}

Pemakaian pengawet juga mempengaruhi kestabilan emulsi kosmetik karena kehadiran mikroorganisme akan mempengaruhi daya awet, keadaan fisik, dan keadaan kimia emulsi yang dihasilkan (Mitsui 1997). Hasil uji total mikroba pada pelembab kulit dengan berbagai konsentrasi pektin menunjukkan bahwa untuk ALT Bakteri, AKK, Staphylococcus aureus, dan Pseudomonas aeruginosa tidak terdapat cemaran mikroba. Hasil uji ini menunjukkan bahwa pelembab kulit dengan penambahan konsentrasi pektin aman digunakan.

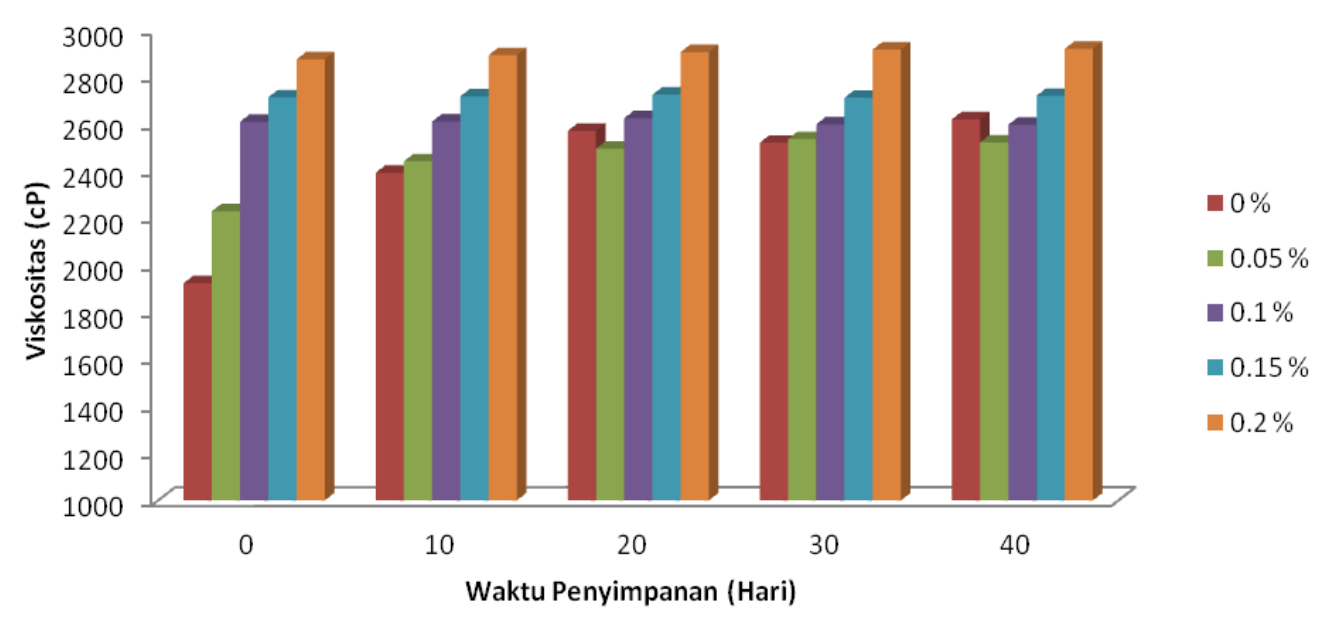

Gambar 5. Histogram Hubungan antara Konsentrasi Pektin dengan Viskositas Selama 40 hari Penyimpanan Suhu Ruang $\left(27^{\circ} \mathrm{C}\right)$ 
Pengawet (metil paraben) yang digunakan sebagai tambahan pada produk menyebabkan mikroba tidak dapat tumbuh karena pengawet bersifat anti mikroba. Pengawet harus ditambahkan pada suhu yang tepat pada saat proses pembuatan pelembab kulit, yaitu antara suhu $35-45{ }^{\circ} \mathrm{C}$ agar tidak merusak bahan aktif yang terdapat dalam pengawet tersebut. Mikroba yang terdapat dalam suatu produk dapat menyebabkan emulsi tidak stabil (Mitsui 1997).

\section{Stabilitas Emulsi}

Perhitungan nilai stabilitas emulsi dilakukan apabila terjadi pemisahan fase. Stabilitas emulsi menunjukkan kestabilan suatu bahan dimana emulsi yang terdapat dalam bahan tidak mempunyai kecenderungan untuk bergabung dengan partikel lain dan membentuk lapisan yang terpisah (Suryani et al. 2000). Emulsi yang tidak stabil akan mengalami perubahan kimia dan perubahan fisika. Perubahan kimia yang terjadi antara lain perubahan warna atau warna memudar, perubahan bau, kristalisasi, dll. Perubahan fisika yang terjadi antara lain pemisahan fase, sedimentasi, pembentukan aggregat, pembentukan gel, penguapan, peretakan, pengerasan, dll (Mitsui 1997). Hasil pengukuran stabilitas emulsi menunjukkan hasil yang sama yaitu $100 \%$. Hasil tersebut memperlihatkan tidak terjadinya perubahan pada emulsi selama penyimpanan pada suhu ruang $\left(27{ }^{\circ} \mathrm{C}\right)$ antara lain tidak terjadinya pemisahan antara fase terdispersi dengan fase pendispersi, tidak menyebabkan terjadinya sedimen, peretakan emulsi dan pembentukan gel serta adanya perubahan bau dan warna setelah proses pengujian stabilitas emulsi dilakukan. Hal ini diduga karena emulsi yang dihasilkan mengalami penyimpanan suhu ruang sehingga stabilitas emulsi pelembab kulit yang dihasilkan sama dan memperlihatkan tanda-tanda emulsi yang stabil.

\section{Pengujian Mutu Pelembab Kulit Setelah 40 Hari Penyimpanan Suhu $45^{\circ} \mathrm{C}$}

1. Penampakan
Penampakan pelembab kulit penyimpanan suhu ruang $\left(27^{\circ} \mathrm{C}\right)$ setelah 40 hari, mengalami perubahan relatif kecil jika dibandingkan dengan pelembab kulit sebelum penyimpanan pada penyimpanan suhu ruang, jadi produk relatif stabil terlihat dari luar.

\section{Nilai $\mathrm{pH}$}

Nilai $\mathrm{pH}$ sangat penting pada pelembab kulit yang berkenaan dengan kulit karena kulit memiliki batas $\mathrm{pH}(4,5-8,0)$ yang tidak menyebabkab kulit mengalami kerusakan. Nilai rata-rata $\mathrm{pH}$ untuk produk pelembab kulit yang mengalami penyimpanan suhu 45 ${ }^{\circ} \mathrm{C}$ setelah 40 hari, tidak mengalami perubahan yang jauh. Nilai rata-rata $\mathrm{pH}$ yang didapat masih berkisar antara 7,007,10 . Nilai $\mathrm{pH}$ produk pelembab kulit yang baik yaitu masih masuk rentang SNI yaitu antara 4,5-8,0.

\section{Nilai Bobot Jenis}

Bobot jenis pelembab kulit setelah 40 hari penyimpanan pada suhu $45{ }^{\circ} \mathrm{C}$, masih sesuai dengan standar SNI 16-4399-1996 yaitu 0,95-1,05 g/ml, karena konsentrasi pektin yang relatif kecil pada pelembab kulit, sehingga penambahan berbagai konsentrasi tersebut tidak memberikan pengaruh yang berarti terhadap BJ pelembab kulit.

\section{Viskositas}

Viskositas produk pelembab kulit mengalami perubahan selama penyimpanan, yaitu adanya kecenderungan peningkatan. Secara umum, viskositas emulsi meningkat dengan bertambahnya umur sediaan tersebut (Rieger 1994).

Hasil pengukuran nilai viskositas selama penyimpanan menunjukkan produk dengan konsentrasi pektin $0 \%$ sampai 0,2 $\%$, viskositas mengalami perubahan semakin meningkat sampai pada pengamatan hari ke 10 pada suhu $45^{\circ} \mathrm{C}$. Sifat pektin menjadi tidak optimum pada suhu $45{ }^{\circ} \mathrm{C}$, sehingga produk tanpa pektin mengalami peningkatan viskositas yang sama dengan semua penambahan konsentrasi pektin sampai dengan 0,2 \%. Viskositas emulsi akan mengalami perubahan untuk beberapa lama 
dan kemudian relatif konstan. Nilai viskositas dengan penambahan pektin selama penyimpanan 40 hari pada suhu 45 ${ }^{\circ} \mathrm{C}$ masih termasuk ke dalam kisaran viskositas yang disyaratkan SNI 16-43991996 yaitu berada dalam kisaran nilai viskositas 2000-50000 cP.

Berdasarkan analisis ragam dapat diketahui bahwa konsentrasi pektin, lama penyimpanan dan interaksi antara konsentrasi pektin dengan lama penyimpanan mempengaruhi viskositas. Pektin memiliki komponen hidrofilik sehingga pengikatan air oleh pektin lebih banyak terjadi akibatnya viskositas pelembab kulit meningkat. Akan tetapi, selama proses penyimpanan suhu 45 ${ }^{\circ} \mathrm{C}$ kemungkinan ada sebagian air yang menguap sehingga mempengaruhi viskositas produk. Suhu juga mempengaruhi sifat pektin sebagai pengental karena, ketika proses penambahan pektin saat pemanasan pada prosedur pembuatan, dapat mengakibatkan produk menjadi tidak lebih kental dibandingkan dengan tanpa penambahan pektin.

\section{Total Mikroba}

Tumbuhnya mikroba dapat menyebabkan kerusakan pada produk yang mengalami penyimpanan. Tempat penyimpanan, kemasan dan suhu antara lain faktor yang dapat menyebabkan tumbuhnya mikroorganisme pada suatu produk. Berdasarkan uji yang telah dilakukan tidak terdapat mikroorganisme yang tumbuh setelah produk disimpan pada suhu $45{ }^{\circ} \mathrm{C}$. Hal ini terjadi akibat penambahan pengawet pada produk. Pengawet (metil paraben) yang ditambahkan terbukti efektif untuk mencegah tumbuhnya mikroorganisme yang merusak.

\section{Stabilitas Emulsi}

Stabilitas emulsi menunjukkan kestabilan suatu bahan dimana emulsi yang terdapat dalam bahan tidak mempunyai kecenderungan untuk bergabung dengan partikel lain dan membentuk lapisan yang terpisah (Suryani et al. 2000). Emulsi yang tidak stabil akan mengalami perubahan kimia dan perubahan fisika. Hasil pengukuran stabilitas emulsi menunjukkan hasil yaitu untuk kestabilan emulsi pektin dengan konsentrasi $0,15 \%$ masih stabil di suhu $45{ }^{\circ} \mathrm{C}$ dan pada penambahan pektin $0,20 \%$ ada ketidakstabilan emulsi. Hal ini dikarenakan suhu penyimpanan yang meningkat. Nilai kestabilan emulsi produk pelembab kulit dengan penambahan pektin $0,20 \%$ sebesar 93,77 \%. Hasil tersebut memperlihatkan terjadinya pemisahan antara fase terdispersi dengan fase pendispersi.

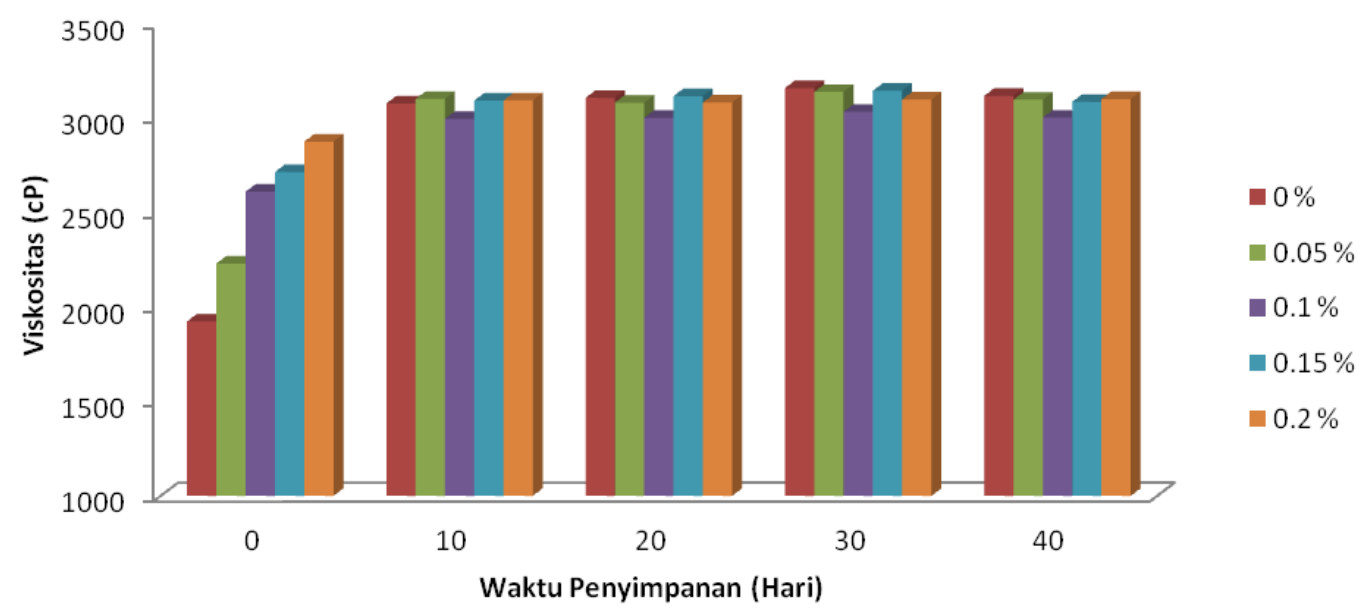

Gambar 6. Histogram Hubungan antara Konsentrasi Pektin dengan Viskositas Selama 40 Hari Penyimpanan Suhu $45^{\circ} \mathrm{C}$ 


\section{KESIMPULAN DAN SARAN}

\section{Kesimpulan}

a. Berdasarkan hasil penelitian yang telah dilakukan tentang pengaruh konsentrasi pengental pektin dalam suhu dan waktu penyimpanan berbeda terhadap parameter fisika pada formulasi pelembab kulit dapat disimpulkan bahwa produk terbaik diperoleh dari penambahan pektin $0,05 \%$ dengan karakteristik penampakan (kekentalan) yang paling disukai, nilai $\mathrm{pH} 7,08$; bobot jenis $0,98 \mathrm{~g} / \mathrm{ml}$; viskositas 2229 cP, stabilitas emulsi $100 \%$, dan tidak terdapat cemaran mikroba sesuai dengan syarat mutu pelembab kulit (berdasarkan SNI 16-4399-1996).

b. Setelah penyimpanan pada suhu ruang $27{ }^{\circ} \mathrm{C}$ dan suhu $45^{\circ} \mathrm{C}$ setelah 40 hari, nilai $\mathrm{pH}$, bobot jenis, cenderung stabil sedangkan nilai viskositas mengalami peningkatan, dan kestabilan emulsi masih stabil.

\section{Saran}

a. Penambahan pektin pada pelembab kulit berdasarkan kestabilan emulsi $45^{\circ} \mathrm{C}$ sebaiknya tetap $<0,15 \%$ supaya produk tetap stabil.

b. Pektin dapat digunakan sebagai pengental $<0,15 \%$.

\section{DAFTAR PUSTAKA}

Mitsui. 1997. New Cosmetic Science. Elsevier. NewYork

Ötles. 2004. Acrylamide in Food. Electronic Journal of Enviromental, Agricultural and Food Chemistry: 723, 724, 725,726.

Richard ,J.1984. Carcinogenic Effects of Acrylamide in Sencar and A/J Mice. Bull of Cancer Research, 107-111
Rieger, M. 1994. Harry's Cosmeticology. Ed ke-8. Chemical Publishing Co Inc. New York

Schmitt, W.H. 1996. Skin Care Products. Di dalam: DF Williams and WH Schmitt (Ed). 1996. Chemistry and Technology of Cosmetics and Toiletries Industry. Ed ke-2. Blackie Academy and Profesional. London

[SNI] Standar Nasional Indonesia 164399. 1996. Sediaan Tabir Surya. Badan Standarisasi Nasional. Jakarta

Suryani, A., I. Sailah, dan E. Hambali. 2000. Teknologi Emulsi. Jurusan Teknologi Industri Pertanian, Fakultas Teknologi Pertanian, Institut Pertanian Bogor. Bogor.

Susanto, T., S. Yuwono. 2001. Pengujian Fisik Pangan. Unesa Press. Surabaya.

Wasitaatmadja, S.M,. 1997. Penuntun Ilmu Kosmetik Medik. UI Press. Jakarta. 
Lampiran 1. Diagram Alir Pembuatan Pelembab Kulit dengan Pengental Pektin

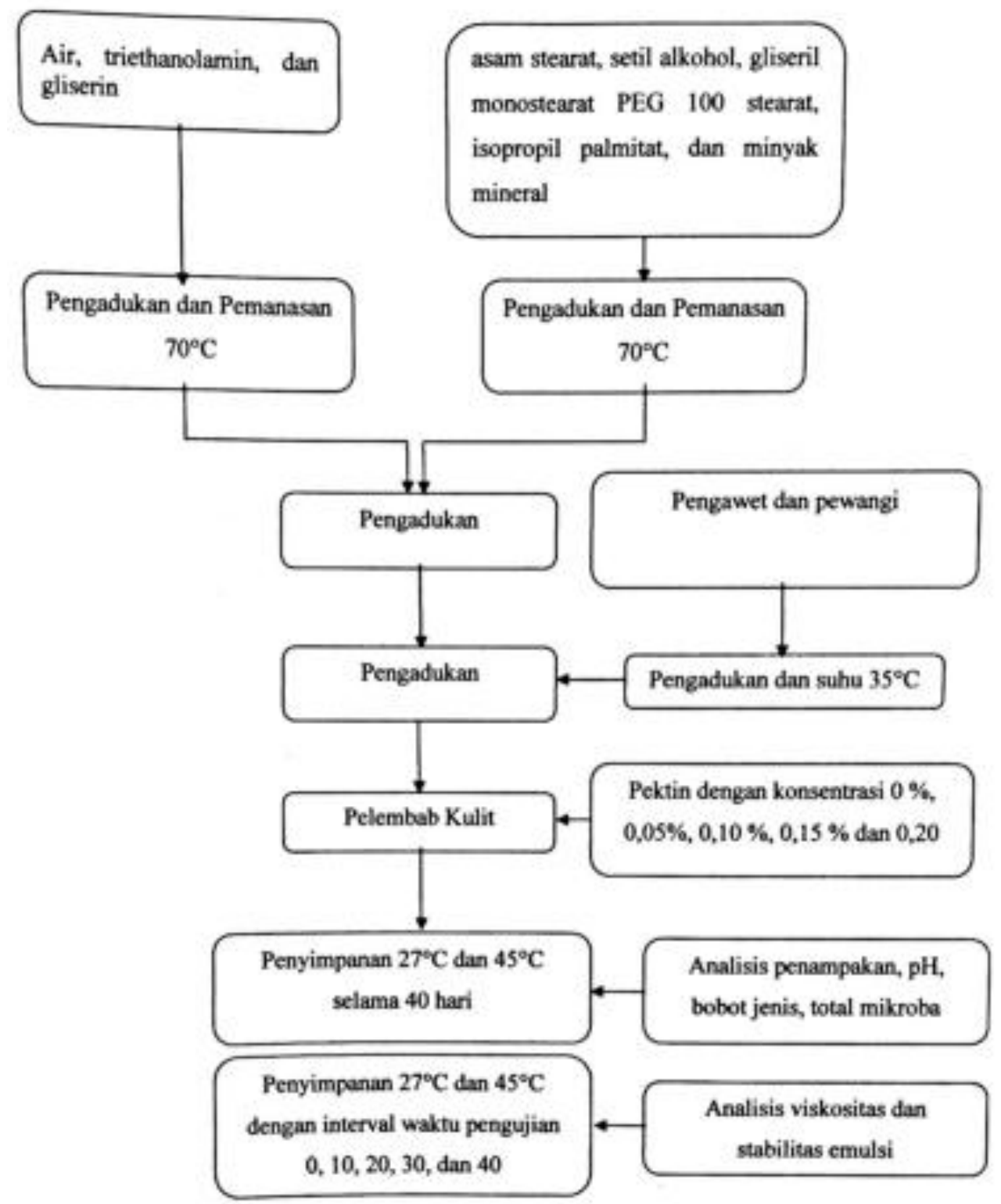


Lampiran 2. Rancangan Acak Lengkap (RAL) Pola Faktorial Pengujian Mutu untuk Parameter pH Tabel Dua Arah antara Faktor Konsentrasi Pektin dan Parameter pH

\begin{tabular}{|l|r|r|r|r|}
\hline \multirow{2}{*}{$\begin{array}{c}\text { Konsentrasi } \\
\text { Pektin }(\%)\end{array}$} & \multicolumn{3}{|c|}{ Ulangan } & \multicolumn{1}{|c|}{ Total } \\
\cline { 2 - 4 } $\mathbf{0}$ & $\mathbf{1}$ & $\mathbf{2}$ & $\mathbf{3}$ & \\
\hline $\mathbf{0 , 0 5}$ & $\mathbf{7 , 1 0}$ & $\mathbf{7 , 1 1}$ & $\mathbf{7 , 1 0}$ & $\mathbf{2 1 , 3 1}$ \\
\hline $\mathbf{0 , 1 0}$ & $\mathbf{7 , 0 8}$ & $\mathbf{7 , 0 8}$ & $\mathbf{7 , 0 8}$ & $\mathbf{2 1 , 2 4}$ \\
\hline $\mathbf{0 , 1 5}$ & $\mathbf{7 , 0 6}$ & $\mathbf{7 , 0 5}$ & $\mathbf{7 , 0 6}$ & $\mathbf{2 1 , 1 7}$ \\
\hline $\mathbf{0 , 2 0}$ & $\mathbf{7 , 0 3}$ & $\mathbf{7 , 0 2}$ & $\mathbf{7 , 0 3}$ & $\mathbf{2 1 , 0 8}$ \\
\hline Total & $\mathbf{7 , 0 2}$ & $\mathbf{7 , 0 1}$ & $\mathbf{7 , 0 0}$ & $\mathbf{2 1 , 0 3}$ \\
\hline
\end{tabular}

$\begin{array}{ll}\text { Faktor Koreksi } & \mathbf{7 4 6 , 7} \\ \text { JK Total } & \mathbf{0 , 0 1 7 7 7} \\ \text { JK pH } & \mathbf{0 , 0 1 7 3 7} \\ \text { JK Galat }(\mathbf{G}) & \mathbf{0 , 0 0 0 4}\end{array}$

Tabel Daftar Sidik Ragam

\begin{tabular}{|l|l|l|l|l|l|l|l|l|}
\hline SK & Db & JK & KT & Fhit & \multicolumn{2}{|l|}{ Ftab } & \multicolumn{2}{l|}{ Pengambilan keputusan } \\
\cline { 1 - 4 } & & & & & $\mathbf{5 \%}$ & $\mathbf{1 \%}$ & \multicolumn{2}{l|}{} \\
\hline pH & $\mathbf{4}$ & $\mathbf{0 , 0 1 7}$ & $\mathbf{0 , 0 0 4 2 5}$ & $\mathbf{1 0 6 , 2 5}$ & $\mathbf{3 , 4 8}$ & $\mathbf{5 , 9 9}$ & Fhit>Ftab & $\begin{array}{l}\text { Ho ditolak } \\
(\mathbf{P}<\mathbf{0 , 0 1})\end{array}$ \\
\hline Galat & $\mathbf{1 0}$ & $\mathbf{0 , 0 0 0 4}$ & $\mathbf{0 , 0 0 0 0 4}$ & & & & & \\
\hline Total & $\mathbf{1 4}$ & $\mathbf{0 , 0 1 0 4}$ & & & & & & \\
\hline
\end{tabular}


Lampiran 3. Rancangan Acak Lengkap (RAL) Pola Faktorial untuk Parameter Visikositas Saat Penyimpanan Suhu Ruang $\left(27^{\circ} \mathrm{C}\right)$ Selama 40 Hari

Tabel Dua Arah antara Konsentrasi Pektin dan Faktor Interval Penyimpanan

\begin{tabular}{|c|c|c|c|c|c|c|}
\hline \multirow{2}{*}{$\begin{array}{l}\text { Konsentrasi } \\
\text { Pektin (\%) }\end{array}$} & \multicolumn{5}{|c|}{ Interval Penyimpanan } & \multirow[t]{2}{*}{ Total } \\
\hline & $\mathbf{0}$ & 10 & 20 & 30 & 40 & \\
\hline 0 & 5770 & 7177 & 7709 & 7561 & 7858 & 36075 \\
\hline $\mathbf{0 , 0 5}$ & 6686 & 7324 & 7481 & 7604 & 7563 & 36658 \\
\hline $\mathbf{0 , 1 0}$ & 7828 & 7829 & 7872 & 7793 & 7787 & 39109 \\
\hline $\mathbf{0 , 1 5}$ & 8140 & 8152 & 8171 & 8133 & 8156 & 40752 \\
\hline $\mathbf{0 , 2 0}$ & 8623 & 8675 & 8714 & 8749 & 8756 & 43517 \\
\hline Total & 37047 & 39157 & 39947 & 39840 & 40120 & 196111 \\
\hline
\end{tabular}

JK Perlakuan

JK Konsentrasi Pektin

JK interval Penyimpanan

JK Toatal

JK Interaksi (JS)

JK Galat (G)

\section{4,7}

2485226,6

429920,2

3677307,4

720527,9

41632,7

Tabel Daftar Sidik Ragam

\begin{tabular}{|c|c|c|c|c|c|c|c|c|}
\hline \multirow[t]{2}{*}{ SK } & \multirow[t]{2}{*}{ Db } & \multirow[t]{2}{*}{ JK } & \multirow[t]{2}{*}{ KT } & \multirow[t]{2}{*}{ Fhit } & \multicolumn{2}{|c|}{ Ftab } & \multirow{2}{*}{\multicolumn{2}{|c|}{ Pengambilan Keputusan }} \\
\hline & & & & & $5 \%$ & $1 \%$ & & \\
\hline $\begin{array}{l}\text { Konsentrasi } \\
\text { Pektin }\end{array}$ & 4 & 2485226,6 & 621306,6 & 746,2 & 2,56 & 3,72 & Fhit $>$ Ftab & Ho ditolak \\
\hline $\begin{array}{l}\text { Interval } \\
\text { Penyimpanan }\end{array}$ & 4 & 429920,2 & 107480,0 & 129,1 & 2,56 & 3,72 & Fhit $>$ Ftab & Ho ditolak \\
\hline JS & 16 & 720527,9 & 45033,0 & $\overline{54,1}$ & 2,56 & 3,72 & Fhit $>$ Ftab & Ho ditolak \\
\hline Galat (G) & 50 & 41632,7 & 832,7 & & & & & \\
\hline
\end{tabular}


Lampiran 4. Rancangan Acak Lengkap (RAL) Pola Faktorial untuk Parameter Visikositas Saat Penyimpanan Suhu $45^{\circ} \mathrm{C}$ Selama 40 Hari

Tabel Dua Arah antara Konsentrasi Pektin dan Faktor Interval Penyimpanan

\begin{tabular}{|c|c|c|c|c|c|c|}
\hline \multirow{2}{*}{$\begin{array}{l}\text { Konsentrasi } \\
\text { Pektin }(\%)\end{array}$} & \multicolumn{5}{|c|}{ Interval Penyimpanan } & \multirow[t]{2}{*}{ Total } \\
\hline & $\mathbf{0}$ & $\mathbf{1 0}$ & 20 & 30 & 40 & \\
\hline $\mathbf{0}$ & 5770 & 9227 & 9316 & 9472 & 9348 & 43133 \\
\hline $\mathbf{0 , 0 5}$ & 6686 & 9299 & 9239 & 9412 & 9287 & 43923 \\
\hline $\mathbf{0 , 1 0}$ & 7828 & 8983 & 8999 & 9096 & 9002 & 43908 \\
\hline $\mathbf{0 , 1 5}$ & 8140 & 9272 & 9346 & 9429 & 9253 & 45440 \\
\hline $\mathbf{0 , 2 0}$ & 8623 & 9277 & 9242 & 9292 & 9297 & 45731 \\
\hline Total & 37047 & 46058 & 46142 & 46701 & 46187 & 222135 \\
\hline
\end{tabular}

JK Perlakuan

JK Konsentrasi Pektin

JK interval Penyimpanan

JK Toatal

JK Interaksi (JS)

JK Galat (G)
6456138

328293,2

4555630,8

6618216

1572214

162078

Tabel Daftar Sidik Ragam

\begin{tabular}{|c|c|c|c|c|c|c|c|c|}
\hline \multirow[t]{2}{*}{ SK } & \multirow[t]{2}{*}{ Db } & \multirow[t]{2}{*}{ JK } & \multirow[t]{2}{*}{ KT } & \multirow[t]{2}{*}{ Fhit } & \multicolumn{2}{|c|}{ Ftab } & \multirow{2}{*}{\multicolumn{2}{|c|}{ Pengambilan Keputusan }} \\
\hline & & & & & $5 \%$ & $1 \%$ & & \\
\hline $\begin{array}{l}\text { Konsentrasi } \\
\text { Pektin }\end{array}$ & 4 & 328293,2 & 82073,30 & 25,32 & 2,56 & 3,72 & Fhit $>$ Ftab & Ho ditolak \\
\hline $\begin{array}{l}\text { Interval } \\
\text { Penyimpanan }\end{array}$ & 4 & 4555630,8 & 1138907,7 & 351,35 & 2,56 & 3,72 & tab & Ho \\
\hline JS & 16 & $\mathbf{1 5 7 2 2 1 4}$ & 98263,38 & 30,31 & 2,56 & 3,72 & Fhit > Ftab & olak \\
\hline Galat (G) & 50 & 162078 & 3241,56 & & & & & \\
\hline
\end{tabular}

